\title{
Tourism demand in Asean-5 countries: Evidence from panel data analysis
}

\author{
Nur Fadzlunnisaa Wakimin ${ }^{\mathrm{a}}$, A.A. Azlina ${ }^{\mathrm{a}}{ }^{*}$ and Samsudin Hazman ${ }^{\mathrm{a}, \mathrm{b}}$
}

${ }^{a}$ School of Social and Economic Development, Universiti Malaysia Terengganu, 21030 Kuala Terengganu, Terengganu, Malaysia ${ }^{b}$ Kenyir Research Institute, Universiti Malaysia Terengganu, 21030 Kuala Terengganu, Terengganu, Malaysia

\begin{tabular}{l}
\hline C H R O N I C L E \\
\hline Article history: \\
Received: November 26, 2017 \\
Received in revised format: Janu- \\
ary 31, 2018 \\
Accepted: April 7, 2018 \\
Available online: \\
April 8, 2018 \\
\hline Keywords: \\
Tourism demand \\
Pooled mean group \\
Sustainable economic growth \\
CO2 emissions \\
Socio-economic development
\end{tabular}

\begin{abstract}
Tourism has emerged as a major industry worldwide and a sector in many countries. This sector has experienced a rapid growth and has become a key driver for sustainable socioeconomic developments globally. However, tourism is also a vector of environmental degradation through the emission of greenhouse gases (GHG). Therefore, the aim of this study was to analyze the main factors that are affecting the tourism demand in ASEAN-5 countries. Using a panel of five ASEAN countries over a 44-year period and applying the Pooled Mean Group (PMG) approach, the empirical results have shown that the major determinants of tourism demand in these countries are income, trade, tourism price, and carbon dioxide emission. The results have also shown that the PMG performed better than the Mean Group (MG) estimator. This paper refers to the PMG estimator because it constrains the long run coefficients to be identical, but allows the short run coefficients and error variances to differ across groups. Income and trade appeared to exert significant positive impacts on tourism demand, whereas tourism price and carbon dioxide emissions have negative impacts on tourism demand in these ASEAN-5 countries. The results would be a good reference for policy makers in these specific countries.
\end{abstract}

\section{Introduction}

The tourism industry will only grow more rapidly if nature and culture are maintained in their true forms (Association, 2015). However, increased cost of living, traffic congestions, changes in the hosts' way of life, pollution, crowding, and increased crime rates are some of the problems that are currently faced by ASEAN countries in relation to tourism (Andriotis, 2004; Bestard \& Nadal, 2007; Gu \& Ryan, 2008; Trebicky \& Cihar, 2006). The importance of tourism is recognised by most countries in the world and ASEAN countries have also received the positive impacts of this sector. The industry also continues to be a major source of foreign exchange, which contributes to the growth of the Gross Domestic Product (GDP), investment, and employment, as well as strengthening the current accounts of the balance of payments (Qureshi et al., 2017). The most important goal among ASEAN countries is to maintain a close and beneficial cooperation with international and regional organisations that have similar aims

\footnotetext{
* Corresponding author.

E-mail address: aqlina@umt.edu.my (A.A. Azlina) 
and objectives as well as to maintain close cooperation with each other. As a consequence, many empirical studies on the relationship between economic growth and the environment have been conducted in developed and developing countries (Lee \& Brahmasrene, 2013; Ridderstaat et al., 2014; Wu \& Chen, 2015).

Malaysia and Thailand have more prominent tourist arrivals compared to other ASEAN countries, with a rate of 7 - 8\% during the period between 1990 and 2014. 2014 was the best year for tourism in ASEAN countries and in 2013 the data recording 84,956,152 tourist arrivals, which was a $9.4 \%$ increase from $77,644,000$ arrivals, (Bank, 2016). In addition, the latest data from the Singapore Tourism Authority pointed to a growth of $7.9 \%$ in total tourist arrivals between January and November of 2016, with Singapore having the largest share of 11.57 million travellers from Asia (9.1\%). Asian travellers accounted for $77.7 \%$ of all visitors, (Authority, 2017). Additionally, the major contribution of the tourism industry to the GDP in 2014 was the US $\$ 458.0$ billion, (2.6\% of the GDP). In 2015, the tourism industry grew by $3.0 \%$ to US $\$ 471.6$ billion. In 2016, the tourism industry has generated US $\$ 7.2$ trillion $(9.8 \%$ of the global GDP) and created 284 million jobs, (Council, 2016). Tourism services offered by hotels, transportation services, and travel agents are reflections of the economic activity in the tourism industry. The direct contribution of the tourism industry is expected to grow by $3.8 \%$ to US $\$ 684.6$ billion (3.0\% of the GDP) by 2025 , with surveys showing a positive and strong relationship between tourism and economic growth, (Antonakakis et al., 2015). The economists and environmentalists have also investigated the factors that could affect such relationships and their implications from the theoretical, practical, and policy point of views.

As part of the most advanced developing countries in the Association of Southeast Asia Nations (ASEAN), the ASEAN-5 has experienced tremendous tourism development in the past few decades. Tourism development in ASEAN-5 countries has shown a strong interactive connection between economic growth and the environment. The economic transactions in ASEAN countries have played an important role in the tourism industry in the ASEAN-5 countries. Nonetheless, this development has impacted a number of factors that can affect tourism demand, such as tourism price, income per capita, trade trends, and carbon dioxide emission in these ASEAN-5 countries. Therefore, it is important to investigate and analyse the main factors that can affect tourism demand based on the economic growth and the environment in ASEAN-5 countries. To confirm the theory of economy, this study applied three variables, namely, tourism price, income per capita, and trade. These factors can show how a country's tourism industry could benefit when the local prices are reduced or by offering better exchange rates to entice tourists to visit. This study has chosen carbon dioxide emission to assess environmental issues that are affecting the tourism sector. The preservation of the environmental surroundings is important because tourists prefer to visit places with the unspoilt environment. Economic growth and the environment have been shown to have both positive and negative relationships. Meanwhile, the local prices and economic growth could indirectly help the tourism sector. The economic growth could also lead to better infrastructure, but high local prices could have a negative effect on tourism.

This study has analysed the main factors that are affecting tourism demand in ASEAN-5 countries, namely, Malaysia, Indonesia, Singapore, Thailand, and the Philippines. Tourism panel data that cover a 44-year period were analysed using the Pooled Mean Group (PMG) approach. The main reason for using panel data was because it allows the sample size to be expanded. It can also control individual heterogeneity, and identify an effect that would simply be undetectable in pure time series data. This study also offers new evidence for ASEAN-5 countries, which is focused on the factors that can affect tourism demand. This approach is of interest because the rising tourist arrivals to ASEAN countries are due to several natural and non-natural factors. By focusing on carbon dioxide emission, this study has filled a research gap that was not available in previous studies. This study had also focused on other aspects, other than the economic theory, which were neglected in previous studies. The framework for the analysis was the interactions between the dependent variable (tourist arrivals) and the independent variables (tourism price, income per capita, trade, and carbon dioxide emission). 
The panel data approach used two procedures; first, it estimated several equations and examined the estimated coefficient across groups. Of particular importance in this study is the mean of the estimates, known as the Mean Group (MG) estimator. The MG estimator would produce consistent estimates for the average values of each parameter. The mean group estimator does not take into account that certain parameters may be the same across groups (Pesaran \& Smith, 1995). The second procedure implemented the traditional pooled estimator, whereby other coefficients and error variances were constrained to be the same, but the intercepts were permitted to differ across groups. The Pooled Mean Group (PMG) estimators, which involved pooling and averaging, were applied. The PMG let the intercepts and short run coefficients be different freely across groups but constrained the long run coefficients.

ASEAN-5 countries are the growing regions among ASEAN countries, and the growing tourism demand in ASEAN countries will have serious implications on tourism price and carbon dioxide emissions. Based on the economic theory, long run tourism demand on tourism price and carbon dioxide emission would be a negative relationship. However, short run adjustments depend on the fluctuating rate of tourist arrivals and other factors that determine tourism demand in ASEAN-5 countries, which would unlikely, be homogeneous across countries. Therefore, the PMG estimator allowed long run homogeneity analysis without imposing parameter homogeneity onto short run factors.

The policy makers, relevant industries, and governments in other countries have important economic consequences in international tourism demand. The implementation of long run policies is important to reduce any risks and to increase the probability of achieving the desired goals. Tourism demand needs to be underpinned by a policy framework that supports the development and implementation of investment planning. It also needs a legislative timetable to support the key actions identified by stakeholders. The results of this study would be important references for ASEAN-5 countries, in their effort to formulate long run tourism policies that would ensure long run tourist arrivals and environmental sustainability, without having to jeopardize economic growth. This paper will discuss selected literature in the review and then proceeds to the model and specifications and source of data. This review will also present the interpretation of econometrics analysis and will conclude with several policy recommendations.

\section{Literature Review}

The tourism industry has become one of the major contributors to the economic growth, investment, and employment in ASEAN countries through foreign exchange. This is evidenced by the increasing contribution of the tourism industry to the country's revenue. This will indirectly affect the total employment rate in ASEAN countries. the role of the exchange rate and tourism costs are equally important because a depreciation of the Ringgit Malaysia (RM) and lower costs would attract more tourists to Malaysia, (Kosnan et al., 2013). This study has found that income per capita and tourism price are the most explanatory variables. The theory of economic demand suggests that when the income of a country increases, it can increase the ability of its citizens to visit other countries. In other words, tourist arrivals are a positive function of income, (Garin-Munoz \& Amaral, 2000).

The substantial effect of the selected economic and non-economic factors in detecting international tourist arrivals from ASEAN countries to Malaysia was accomplished by Kusni et al. (2013). They reported that the relative price of tourism, personal income, substitute price, and dummy variables for the Asian Financial Crisis and Tsunami aftermath were meaningful in describing the international tourist arrivals from ASEAN countries to Malaysia. They have also concluded that Singapore was a substitute destination for Malaysia, whereas Thailand was considered as a complementary destination. In the study by Tourism Research Australia, it was found that one of the factors that were affecting the tourism sector in that country was income, (Research, 2016). Although the Australian dollar has appreciated strongly in recent years, there were significant changes in real income, when the western market 
was experiencing poor economic growth, while the eastern market was experiencing good economic growth, (Research, 2011). When using the heterogeneous coefficients in Panel Data, both of the heterogeneity and cross-sectional had intersected at the panel time-series estimators, (Neal, 2015). Meanwhile, that the challenge to be tackled in the future would be to improve the small properties of the estimator, (Tang \& Tan, 2015).

The importance of tourism demand for local market demand and the demand for tourism products in rural and urban areas, (Garcia et al., 2005). This strategy was crucial for finding new ideas to develop rural areas. Facilities that meet tourism demands should be sufficient to ensure tourist satisfaction for the short run and the long run. the understanding that tourist seasonal variations were due to the temporary imbalance caused mainly by the higher incidence of tourist activities during certain periods of the year, in which the supply and demand factors are involved, (López Bonilla, 2005).

The Department of Southeast Asian Nation reported that tourists from Singapore, Indonesia, Thailand, and the Philippines have dominated tourist arrivals to Malaysia. Since 1985, approximately 95\% of total tourist arrivals in the ASEAN region have been to Malaysia, (Nation, 2016). The tourism demand has been proxied by tourist arrivals as the dependent variable, (Mervar \& Payne, 2007). The functional analysis of double logarithmic regression model and found that there was a positive relationship between tourist arrivals and revenues, whereby the increasing tourist arrivals would increase the national income as well used by (Aktürk \& Kucukozmen, 2006). On the other hand, tourist arrivals and relative tourism prices have a negative relationship; when the relative price increases, tourist arrivals will decrease.

Tourist arrivals from Germany and Great Britain to Greece from 1960 to 2000 were found to have affected the real income, transportation costs, and exchange rates of Greece in the long run. This analysis was conducted using the Augmented Dickey-Fuller test (ADF) and the Vector Auto regression (VAR) model, (Dritsakis, 2005). To prove the significance of travel costs, the cost of travel was significantly affecting tourism products and tourism management products, (Chaitip et al., 2008). Similarly, tourism demographics were also found to have significantly affected tourism products and tourism management products. When determining the domestic tourism demand by using multiple co-integration analysis, the long run and the short run determinants of tourism spending in Northumbrian were the relative prices of tourism and real income, (Seddighi \& Shearing, 1997). When the tour price is cheaper in Northumbrian, tourist arrivals from the United Kingdom would increase. This result proved that tourism has a relatively negative relationship with income; when income increases, tourist arrivals would be decreased. the preservation and encouragement of local cultures, increase in investments, and an increase in local government's revenues were the three impacts of tourism, (McDowall \& Choi, 2010). These improvements have shown the impact of tourism on the economy, social, and environmental aspects of a country.

The factors that could affect tourism demand include per capita income, travel costs, relative price levels, and exchange rates, (Nation, 2013). Additionally, the population variable, uniformity of language, and tourist attractions, such as the local climate and culture, could also affect the arrival of tourists into the country. The increase in tourist income would increase the demand for tourism, (Schubert et al., 2011). This situation may affect the capital growth rate, and thus, the production cost of travel and tourism services would steadily increase. In turn, these growths would attract more stout investments in tourism spending and would increase the economic growth. It was also found that the long run increase in GDP per capita in the United States had resulted in the increase in GDP per capita in Antigua and Barbuda. Therefore, their study, which was conducted using co-integration analysis and dynamic model, has shown that tourism can drive economic growth.

Most researchers in the mid-1990s used dynamic analysis, such as co-integration analysis in their work. The good method for regression problems that are encountered when using non-stationary data in the 
econometric analysis, which was included in the tourism demand analysis is one of the methods was pioneered by (Engle \& Granger, 1987). Other researchers have also developed co-integration methods, such as co-integration in a multivariate model by (Johansen \& Juselius, 1990). Meanwhile, known as Co-integration Autoregressive Distributed Lag (ARDL) has developed by (Pesaran \& Smith, 1995). Several studies on tourism have used this method to avoid the adverse effect of multicollinearity, which is often associated with the inclusion of lag variables as regressors, (Narayan, 2004; Norlida Hanim Mohd Salleh, 2011; TOH, 2006).

The increase in tourist revenue would increase tourism demand, a recent study by (Schubert et al., 2011). This situation was found to affect the capital growth rate, and thus, the production costs of travel and tourism services were also increased. This increment had attracted more investments in tourism expenditure and increased the rate of economic growth. A frequent problem faced in the field of tourism research is insufficient data. However, this problem can be solved using panel data analysis, which can also increase the estimator's capacity.

\section{Methodology}

This current study was focused on the ASEAN-5 countries because they play an important role in foreign tourist arrivals. This study has analysed the main factors that were affecting tourism demand in these countries. A panel data approach was developed to study the demand of tourists for each country. Data were collected from the Statistics Tourism Malaysia, the Ministry of Tourism, the World Tourism Organization, the United Nations Statistics Division, and the World Development Indicators for the period between 1970 and 2014. A regression model was used in this study to determine the typical formulation economic theory for aggregate tourism demand functions. The dependent variable was Tourist Arrival (TA), while the independent variables consisted of Tourism Price (TP), Income Per Capita (INC), Trade (TRD), and Carbon Dioxide Emission $\left(\mathrm{CO}_{2}\right)$.

\subsection{The Econometric Approach}

This study has examined the tourism demand in a panel data framework. The main reason for using panel data was because it allows the expansion of the sample size. This feature was important because this model needs to analyse tourism demand from a number of different areas. Tourism demand patterns would vary significantly over time, and this model could indirectly fix the issues that cross-sectional data would fail to address. The benefit of panel data is that it has larger data sets, with lesser collinearity and more variability among the variables compared to typical cross-sectional or time series data, (Baltagi \& Giles, 1998). It would also be able to control individual heterogeneity and identify the effects that would have been undetectable in pure time series data.

\subsection{The dynamic heterogeneous panel data}

The relationships between tourism demand in ASEAN-5 countries and the previously describes determinants required further investigation. Therefore, the estimation technique of MG and PMG would yield estimates that were more reliable. This study estimated the results for three-panel data estimators: mean group (MG), pooled mean group (PMG), and dynamic fixed effects (DFE). The advantages of using the PMG estimator in a dynamic panel econometric technique include allowing short run coefficients, error variances, and speed of adjustment to vary across countries, (Kim, Lin, \& Suen, 2010). In the long run, only have the existence of cross country homogeneity restriction. To examine the long run effects of tourism demand in selected ASEAN countries, the cross-sectional regression was estimated using the following equation:

$$
\begin{gathered}
\text { Tourist arrivals }_{\text {it }}=\beta+\beta \text { tourism price }_{\text {it }}+\beta \text { income per capita }_{\text {it }}+\beta \text { trade }_{i t}+\beta \text { carbon } \\
\text { dioxide emission } \\
\text { it }+\varepsilon_{\text {it }},
\end{gathered}
$$


where tourist arrivals it refers to the number of tourists in period $t$ for country $i$, tourism price it refers to the real price of the consumer price index and exchange rate, while trade ${ }_{\text {it }}$ refers to the trade openness index. Meanwhile, the carbon dioxide emission it refers to the emission of $\mathrm{CO}_{2}$ of matrix per tonnes, and $\varepsilon$ it is the error term. This model can control the heterogeneity in the relationships between tourist arrivals and the selected variables. This model was also able to estimate an empirical model, which was comprised of the effects of the long run and the short run tourist arrivals to the variables from the sample and annual observations. The ARDL for the dependent and independent variables can be written as:

$$
y_{i t}=\mu_{i}+\sum_{j=1}^{p} \lambda_{i j} y_{i t-j}+\sum_{j=0}^{q} \delta_{i j} x_{i t-j}+\mathcal{E}_{i t}
$$

where $1=1,2 \ldots \mathrm{N}$ represents a country, $\mathrm{t}=1,2 \ldots$ T represents the time (at the annual frequency), $j$ represents the number of time lag, $y_{i t}$ represents tourist arrivals, $\mathrm{x}_{\text {it }}$ represents tourism price, income per capita, trade, and carbon dioxide emission, while $\mu_{i}$ represents the fixed effects.

$$
\Delta \mathrm{y}_{\text {it }}=\mu_{\mathrm{i}}+\phi_{\mathrm{i}} \mathrm{y}_{\mathrm{it}-1}+\beta_{\mathrm{i}} \mathrm{x}_{\mathrm{it}}+\sum_{j=1}^{p-1} \lambda^{*}{ }_{\mathrm{ij}} \Delta \mathrm{y}_{\mathrm{it}-\mathrm{j}}+\sum_{j=0}^{q-1} \delta^{*}{ }_{\mathrm{ij}} \Delta \mathrm{x} \text { it-j }+\varepsilon_{\mathrm{it}}
$$

where

$$
\begin{aligned}
& \phi_{\mathrm{i}=-}\left(1-\sum_{j=1 \lambda i j)}^{p} \beta=\sum_{j}^{q} .\right)={ }_{0} \delta_{\mathrm{ij}} \\
& \lambda^{*}{ }_{\mathrm{ij}}=-\sum_{m=j+1}^{p} \lambda_{\mathrm{im}, \mathrm{j}}=1,2, \ldots, \mathrm{p}-1 \\
& \delta^{*}{ }_{\mathrm{ij}=-} \sum_{m=j+1}^{q} \delta_{\mathrm{im}}, \mathrm{j}=1,2, \ldots, \mathrm{q}-1
\end{aligned}
$$

The following Eq. (3) can be rewritten as an error correction equation:

$$
\Delta y_{i t}=\mu_{i}+\phi_{i}\left(y_{i t-1}-\theta_{i} x_{i t}\right)+\sum_{j=1}^{p-1} \lambda^{*}{ }_{i j} \Delta y_{i t-j}+\sum_{j=0}^{q-1} \delta^{*}{ }_{i j} \Delta x_{i t-j}+\mathcal{E}_{i t}
$$

The equation, " $\theta \mathrm{i}=-(\beta \mathrm{i} / \phi \mathrm{i})$ " defines the long run, or equilibrium relationship between $\mathrm{y}$ it and $\mathrm{x}$ it. In contrast, " $\lambda{ }^{*}$ ij" and " $\delta{ }^{*}$ ij" " were the short run coefficients that linked tourist arrival to its past values and other determinants $\left(\mathrm{x}_{i t}\right)$. The error-correction coefficient, " $\phi_{i}$ " measures the speed of adjustment of $\mathrm{y}$ it towards its long run equilibrium, while the change in $\mathrm{x}$ it, " $\Phi{ }_{\mathrm{i}}<0$ " ensures that a long run relationship exists. As a result, a significant and negative value of $\phi_{i}$ was treated as the evidence of cointegration between $\mathrm{y}$ it and $\mathrm{x}$ it.

A simple pooled estimator assumed that the fully homogeneous-coefficient models have a slope and intercept parameters that are restricted to identical values across countries. The fully heterogeneouscoefficient model has also estimated that no cross-country coefficient constraints can be estimated on a country-by-country basis, (Kim et al., 2010). The Mean Group (MG) estimator will provide consistent estimate average of each parameter and under slope heterogeneity, in a small country sample, the Dynamic Fixed Effect (DFE) estimate could be affected by a potential heterogeneity bias (Pesaran \& Smith, 1995). A Pooled Mean Group estimator restricts identical long run parameters over the cross section but allows the intercepts in short run coefficients and error variances to differ across groups on the cross section. If long run homogeneity restrictions are valid, the mean group would be inefficient (Pesaran et al., 1999). Hausman-type statistics can test the validity of the cross-sectional, long run homogeneity restrictions of $\theta_{1}=\theta, i=1,2 \ldots, N$, (Pesaran et al., 1999).

This analysis was based on the developed method of the mixed mean group (MG) and pooled mean group (PMG) estimations. This estimation was used because "the MG estimates are the unweighted mean of the individual regressions on each country, and the PMG estimator estimates common long run coefficients and different short run coefficients", (Sisay, 2015). When the F-statistic was greater 
than the F-critical, the null hypothesis was rejected. This showed that the model of Mean Group (MG) estimators was better to explain the relationships between tourism demand and tourist price, income, trade, and $\mathrm{CO}_{2}$ emission in ASEAN-5 countries. In an opposite situation, when the F-statistic was smaller than the F-critical, the null hypothesis was not rejected. This showed that the estimator model's constant coefficient was better than the model of the Mean Group estimators. The following section will discuss the source of the data used and the description for each determinant factor.

\subsection{The data}

The tourism demand analysis was based on ASEAN-5 countries during the period between 1970 and 2014. Source data was obtained from the World Development Indicators (WDI) at the World Data Bank. The collected data included high levels of performance and different economic developments among these five countries. This study used four indicators of tourist arrivals, namely, tourism price (TP), income per capita (INC), trade (TRD), and carbon dioxide emission $\left(\mathrm{CO}_{2}\right)$. Tourism revenue price calculation was from the Consumer Price Index (CPI), and the exchange rate in each country. The income per capita was derived from the Gross Domestic Product values collected from 1970 until 2014. The trade value was derived from the sum of exports and imports per year in each country. In addition, the value of carbon dioxide emission was obtained from the total value of the concentration of metric tonnes. The descriptions for each variables used are given in Table 1.

\section{Table 1}

Description and unit of the data

\begin{tabular}{lcc}
\hline Variable & Data Description & Unit of measurement (Sources) \\
\hline TA & Tourism Arrival & Total of Tourist Arrivals \\
TP & Tourism Price & Total value of Consumer Price Index (CPI) and Exchange \\
& Rate by country \\
$\mathrm{INC}$ & Income per capita & Gross Domestic Product Value \\
$\mathrm{TRD}$ & Trade & Adding from Export and Import \\
$\mathrm{CO}_{2}$ & Carbon Dioxide Emission & Value of Metric Tonnes \\
\hline
\end{tabular}

A majority of researchers used the number of tourist arrivals as a proxy for the demand of tourism, (Crouch, 1994; Gang Li et al., 2005; Lim, 1997; Witt \& Witt, 1995). This current study has used the same variables. The total of 37 studies had chosen tourist arrivals as the dependent variable, (Li, 2004). The independent variables often used in the analysis of tourism demand are price and tourism income. According to the theory of demand, price and tourism income play important roles in tourism demand. Data on tourist arrivals from ASEAN-5 countries between 1970 and 2004 were collected by the United Nations Statistics Division (Annual Statistical Report). The increase in the number of tourists to a country indirectly represents an increase in the demand for international travel. To strengthen the empirical results, this study has included a major variable in the tourism demand in ASEAN-5 countries, which was tourism price. The mean tourism price is the price of the goods and services used by tourists when they arrive at the destination country. Tourism price was calculated based on the consumer price index (CPI) of the visited country (for example, Indonesia) divided by the Consumer Price Index (CPI) of another country (for example, Malaysia, Singapore, Thailand, or the Philippines), which is multiplied by the value of the exchange rate (ER) of the visited country divided by the ER of another country, (Dritsakis, 2005).

$$
\frac{\text { CPI (Indonesia) }}{\text { CPI (M.S.T.P) }} \times \frac{\text { Exchange Rate (Indonesia) }}{\text { Exchange Rate (M.S.T.P) }}
$$

Tourism price is a proxy for the cost of living relative to each ASEAN country. Normally, tourist arrivals and tourism price would have a negative relationship. The income per capita refers to the real per capita income (RPI). Income per capita is one of the most popular variables that represent tourism demand, (Garin-Munoz \& Amaral, 2000). Income per capita was calculated based on the Gross Do- 
mestic Product (GDP) divided by the population of each country. The increase in income will encourage more tourists to arrive, including groups from lower income, who wants to travel. Normally, higher income groups will increase the total number of tourist arrivals.

Income per capita $=\frac{\text { Growth Domestic Product }(G D P)}{\text { Population }}$

For trade, this study has applied the method by (Dollar \& Kraay, 2003). Thus, trade was derived from the sum of exports and imports per year for each country. In addition, trade refers to the value of trade, in addition to the total exports and imports between Malaysia, Indonesia, Thailand, Singapore, and the Philippines.

$$
\text { Trade }=\text { Exports }+ \text { Imports }
$$

The carbon dioxide emission refers to the rate of reaction between hydrochloric acid and calcium carbonate. It was calculated from the total concentration of carbon dioxide emissions (metric tonnes). The relationship between carbon dioxide emission and tourist arrivals was negative. When carbon dioxide emission increases, it would cause a reduction in tourist arrivals.

\section{Results and Discussion}

The descriptions for the statistics and correlations of the variables are given in Table 2. This study has observed that the correlations between any pair of five variables were positively and negatively correlated based on the table.

\subsection{Descriptive analysis and Correlation}

Table 2

Descriptive statistic and rank correlation matrix

\begin{tabular}{|c|c|c|c|c|c|}
\hline & Tourist Arrivals & Tourism Price & Income Per Capita & Trade & Carbon Dioxide Emission \\
\hline \multicolumn{6}{|l|}{ I-Summary Statistic } \\
\hline Mean & 4832306 & 1.638194 & 5074.101 & 131.7605 & 339079.7 \\
\hline Median & 3050000 & 0.001432 & 1716.610 & 87.20 & 152332.1 \\
\hline Maximum & 25033000 & 30.89 & 54577.14 & 439.6567 & 5040841 \\
\hline Min & 300293 & 3.38 & 83.522 & 2.106 & 7681.876 \\
\hline Std. Dev & 5072059 & 5.5828 & 9198.139 & 116.7543 & 546275.4 \\
\hline Observations & 215 & 215 & 215 & 215 & 215 \\
\hline \multicolumn{6}{|c|}{ II - Rank Correlation Matrix } \\
\hline Tourist Arrivals & 1 & 0.044266 & 0.313181 & 0.301758 & 0.003643 \\
\hline Tourism Price & & 1 & -0.103379 & -0.189773 & 0.405780 \\
\hline Income Per Capita & & & 1 & 0.732375 & -0.206406 \\
\hline Trade & & & & 1 & -0.298242 \\
\hline Carbon Dioxide Emission & & & & & 1 \\
\hline
\end{tabular}

There were considerable variations among these variables in ASEAN-5 countries. In Section I, tourist arrival in Thailand was the highest with 25 million tourists, compared to Indonesia with the lowest tourist arrival of 300,293 tourists. With regards to the tourism price, the lowest range was from US\$ 3.38 million in Singapore to a high tourism price of US\$ 30.89 million in Indonesia. In addition, the income per capita in Indonesia was the lowest at US\$83.52 compared to Singapore, which has the highest income per capita of US\$5,4577.14 among the ASEAN-5 countries. For trade, the highest was in Singapore with US\$439.65 million compared to in the Philippines, which was the lowest at US\$2.106 million. Additionally, Indonesia has shown the highest value for carbon dioxide emission at $5,040,841$ metric tonnes, compared to Singapore with the lowest value of 7,681.876 metric tonnes. Based on these results, no scaling problem was detected and no further modification to the data was required. The result also showed that the data spread was in the small range because the standard deviation was small in all cases. 
For the rank correlation matrix, the results have shown that the cross-correlation between the regressors was relatively small. It indicated that the multicollinearity was unlikely and all regressors did not exceed the $90 \%$ correlation. The correlation results indicated that all variables have positive relationships with tourist arrivals in the correlation. Nevertheless, this study requires further analysis.

\subsection{Panel Co-integration Data}

This step was taken to conduct a panel co-integration estimation test based on the Pooled Mean Group (PMG) approach developed by (Pesaran et al., 1999). The results are summarised in Table 3.

Table 3

The Panel of Co-integration Estimation

\begin{tabular}{|c|c|c|c|c|c|}
\hline & $\begin{array}{l}\text { Long run Coeffi- } \\
\text { cient }\end{array}$ & Short run Coefficient & $\begin{array}{l}\text { Adjustment Coeffi- } \\
\text { cient }\end{array}$ & Constant & $\begin{array}{c}\text { Sample Size } \\
(\mathrm{N} \times \mathrm{T})\end{array}$ \\
\hline \multicolumn{6}{|c|}{ I - Constant (Level) (SBC - 1,1,1,1,1) Maximum lag length set $=4$} \\
\hline Tourism Price & $\begin{array}{l}-0.326826 \\
(0.146668)\end{array}$ & $\begin{array}{c}-0.024420 \\
(0.075164)\end{array}$ & & & \\
\hline Income per capita & $\begin{array}{l}0.590901 * \\
(0.278172)\end{array}$ & $\begin{array}{l}0.2299269 \\
(0.074762)\end{array}$ & & & \\
\hline Trade & $\begin{array}{l}1.0093657 * \\
(0.290761)\end{array}$ & $\begin{array}{c}0.108154 \\
(0.098778)\end{array}$ & & & \\
\hline Carbon Dioxide Emission & $\begin{array}{l}-1.168817 \\
(0.496105)\end{array}$ & $\begin{array}{c}0.112372 \\
(0.077698)\end{array}$ & $\begin{array}{c}-0.090965^{*} \\
(0.041733)\end{array}$ & $\begin{array}{l}1.547421^{*} \\
(0.701489)\end{array}$ & 220 \\
\hline \multicolumn{6}{|c|}{ II - Linear Trend $(\mathrm{SBC}-1,1,1,1,1)$ Maximum lag length set $=4$} \\
\hline Tourism Price & $\begin{array}{l}0.011561^{*} \\
(0.124978)\end{array}$ & $\begin{array}{c}-0.016520 \\
(0.086748)\end{array}$ & \multirow{4}{*}{$\begin{array}{c}-0.233434 * \\
(0.112680)\end{array}$} & & \multirow{4}{*}{220} \\
\hline Income per capita & $\begin{array}{l}0.231564 * \\
(0.126551)\end{array}$ & $\begin{array}{c}0.222184 \\
(0.081277)\end{array}$ & & & \\
\hline Trade & $\begin{array}{l}0.038626 * \\
(0.154886)\end{array}$ & $\begin{array}{c}0.234501 \\
(0.040044)\end{array}$ & & $3.629279^{*}$ & \\
\hline Carbon Dioxide Emission & $\begin{array}{c}-0.286574^{*} \\
(0.203342)\end{array}$ & $\begin{array}{c}0.113911 \\
(0.077381) \\
\end{array}$ & & $(1.743563)$ & \\
\hline
\end{tabular}

Note. A value in parentheses is the standard errors of corresponding estimates. * indicate the significance level of $5 \%$.

The test was based on the Pooled Mean Group (PMG) estimator, which was used to conduct a panel co-integration and provide findings that were more conclusive, (Pesaran et al., 1999). Table 3 shows the summary of the results. The results have been divided into two parts. The first part lists the results obtained at the constant (level) condition, while the second results were obtained with the linear trend condition. Both parts of these results were based on the PMG estimation. As shown in Table 3, the lag length selection was based on the Schwarz Bayesian Criterion (SBC). When the maximum lag length was set at four $(1,1,1,1)$, the number in the square brackets shows the selected optimal lag length. This was because even though the information and data obtained were minimal, the panel co-integration data using SBC was better than using the Akaike Information Criteria (AIC). In addition, the order of Auto-Regressive (AR) seemed preferable. From Table 3, the Error Correction Term (ECT) has also indicated that the tourist arrivals' volatility was corrected by $0.09 \%$ when the first condition was applied and by $0.23 \%$ when the linear trend was over the one-year period. In addition, when there was a change in tourism demand, the rate of tourist arrivals' volatility was restored to its equilibrium, as indicated by the adjustment of ECT. The adjustment of ECT was applied relatively.

\subsection{Pooled Estimation for ARDL}

The estimated results for tourism demand in ASEAN-5 countries are presented in Table 4. The table shows the estimated error correction coefficients, the Hausman test statistics and the long run and short run coefficients. The estimated results were divided into three-panel data estimators, namely, the Pooled Mean Group (PMG), the Mean Group (MG), and the Dynamic Fixed Effect (DFE) models to provide robustness checks. The econometric software used in this study was the Stata 11 . The consistency and efficiency of the PMG estimates relied on several specification conditions. First, to treat the explanatory variables as exogenous, the regression residuals were serially uncorrelated. When the regressor and lags of dependent variables were included, the residuals became serially uncorrelated. The lag order was determined by the Schwarz Bayesian Criterion (SBC), and the recommended lag order was 1 . Second, the coefficient of the error correction term must be negative and significant. 
Table 4

Pooled Estimators for ARDL in ASEAN-5 Countries (1970-2014) Dependent Variable: Tourist Arrivals

\begin{tabular}{|c|c|c|c|c|c|}
\hline & PMG Estimators & MG estimators & $\begin{array}{c}\text { Hausman Tests } \\
\text { (PMG and MG) } \\
0.3553\end{array}$ & DFE Estimators & $\begin{array}{c}\text { Hausman Tests } \\
\text { (MG and DFE) } \\
0.0066\end{array}$ \\
\hline \multicolumn{6}{|c|}{ Long run Coefficients } \\
\hline TP & $\begin{array}{l}-0.3268 \\
(0.1467)\end{array}$ & $\begin{array}{l}-0.1426 \\
(0.4294)\end{array}$ & $\begin{array}{c}-0.3268 \\
(0.5002)\end{array}$ & $\begin{array}{c}0.1099 \\
(0.1143)\end{array}$ & $\begin{array}{c}-0.1426 \\
(8.4244)\end{array}$ \\
\hline INC & $\begin{array}{c}0.5909 \\
(0.2782)\end{array}$ & $\begin{array}{c}1.5519 \\
(0.6518)\end{array}$ & $\begin{array}{c}0.5909 \\
(0.7407)\end{array}$ & $\begin{array}{c}0.4678 \\
(0.3375)\end{array}$ & $\begin{array}{c}1.5519 \\
(12.7845)\end{array}$ \\
\hline TRD & $\begin{array}{c}1.0939 \\
(0.2908)\end{array}$ & $\begin{array}{l}-1.8116 \\
(1.4492)\end{array}$ & $\begin{array}{c}1.0937 \\
(1.7349)\end{array}$ & $\begin{array}{c}0.7874 \\
(0.3239)\end{array}$ & $\begin{array}{l}-1.8116 \\
(28.4317)\end{array}$ \\
\hline $\mathrm{CO} 2$ & $\begin{array}{c}-1.1688 \\
(0.4961) \\
\end{array}$ & $\begin{array}{c}0.8332 \\
(0.8850) \\
\end{array}$ & $\begin{array}{l}-1.1688 \\
(0.9529) \\
\end{array}$ & $\begin{array}{c}-0.1242 \\
(0.6156) \\
\end{array}$ & $\begin{array}{c}0.8332 \\
(17.3539) \\
\end{array}$ \\
\hline \multicolumn{6}{|c|}{ Error Correction Coefficient } \\
\hline Phi & $\begin{array}{l}-0.0910 \\
(0.0417)\end{array}$ & $\begin{array}{l}-0.2209 \\
(0.0961)\end{array}$ & & $\begin{array}{l}-0.0506 \\
(0.0234)\end{array}$ & \\
\hline \multicolumn{6}{|c|}{ Short run Coefficients } \\
\hline TP & $\begin{array}{l}-0.0244 \\
(0.0752)\end{array}$ & $\begin{array}{c}0.0458 \\
(0.1056)\end{array}$ & & $\begin{array}{c}0.0315 \\
(0.0357)\end{array}$ & \\
\hline$\Delta \mathbf{T P}$ & $\begin{array}{c}0.0994 \\
(0.0736)\end{array}$ & $\begin{array}{l}10.4725 \\
(10.589)\end{array}$ & & $\begin{array}{c}0.1271 \\
(0.0709)\end{array}$ & \\
\hline$\Delta \mathbf{T P}(-1)$ & $\begin{array}{c}0.1192 \\
(0.0697) \\
\end{array}$ & $\begin{array}{c}0.0075 \\
(0.0441)\end{array}$ & & $\begin{array}{c}0.4829 \\
(0.0356)\end{array}$ & \\
\hline INC & $\begin{array}{c}0.2293 \\
(0.0748)\end{array}$ & $\begin{array}{c}0.2089 \\
(0.0655)\end{array}$ & & $\begin{array}{c}0.2148 \\
(0.0612)\end{array}$ & \\
\hline$\triangle \mathbf{I N C}$ & $\begin{array}{c}0.8521 \\
(0.0 .1211)\end{array}$ & $\begin{array}{l}-18.3326 \\
(19.152)\end{array}$ & & $\begin{array}{c}0.9396 \\
(0.1789)\end{array}$ & \\
\hline$\Delta \mathrm{INC}(-1)$ & $\begin{array}{c}0.3413 \\
(0.0799)\end{array}$ & $\begin{array}{c}0.3979 \\
(0.0883)\end{array}$ & & $\begin{array}{c}0.2990 \\
(0.0606)\end{array}$ & \\
\hline TRD & $\begin{array}{c}0.1082 \\
(0.0988)\end{array}$ & $\begin{array}{c}0.2100 \\
(0.0543)\end{array}$ & & $\begin{array}{c}0.1248 \\
(0.0632)\end{array}$ & \\
\hline$\triangle$ TRD & $\begin{array}{c}0.4429 \\
(0.0750)\end{array}$ & $\begin{array}{l}37.2445 \\
(37.253)\end{array}$ & & $\begin{array}{c}0.7182 \\
(0.1794)\end{array}$ & \\
\hline$\Delta \operatorname{TRD}(-1)$ & $\begin{array}{c}0.2956 \\
(0.0553)\end{array}$ & $\begin{array}{c}0.1934 \\
(0.0583)\end{array}$ & & $\begin{array}{c}0.2369 \\
(0.0655)\end{array}$ & \\
\hline $\mathrm{CO} 2$ & $\begin{array}{c}0.1124 \\
(0.0777)\end{array}$ & $\begin{array}{c}0.1087 \\
(0.1088)\end{array}$ & & $\begin{array}{c}0.0090 \\
(0.0286)\end{array}$ & \\
\hline$\triangle \mathrm{CO2}$ & $\begin{array}{c}0.1086 \\
(0.2602)\end{array}$ & $\begin{array}{l}-3.4976 \\
(3.3815)\end{array}$ & & $\begin{array}{l}-0.3173 \\
(0.3192)\end{array}$ & \\
\hline$\Delta \mathrm{CO} 2(-1)$ & $\begin{array}{c}0.0654 \\
(0.0492)\end{array}$ & $\begin{array}{c}0.0963 \\
(0.0563)\end{array}$ & & $\begin{array}{c}0.1974 \\
(0.0244)\end{array}$ & \\
\hline Intercept & 0.7837 & 1.8773 & & 0.8255 & \\
\hline NxT & 220 & & 0.6146 & & 0.9626 \\
\hline
\end{tabular}

The error correction term (negative and significant) refers to the existence of a stable, long run relationship (dynamic stability). As reported in Table 4, the coefficient was highly significant and negative in all estimators. Therefore, the evidence supported the existence of stable, long run relationships between tourism price, income per capita, trade, and carbon dioxide emission with tourist arrivals. The final condition required that the long run parameters were the same across countries. In other words, the existence of homogeneity was a must or otherwise, the validity of the estimated result would be questionable. For this purpose, the null hypothesis of homogeneity was tested using the Hausman test, which compared the PMG and the MG estimators. The Hausman test statistics relied on the corresponding p-values based on the coefficients of each explanatory variable. In all panel data estimations, the Hausman test was unable to reject the homogeneity restriction. The estimated results showed that the parameters were homogeneous across countries, and thus, validated the findings. Among the tested estimators, the PMG method provided the best estimates of the long run parameters. Therefore, the discussions in this paper had focused mainly on the PMG estimator. However, the results of another test (MG and DFE) were also provided for robustness checks.

\subsubsection{The Result of a Long run Effect on Tourist Arrivals}

As presented in Table 4, tourism price was found to be an important factor that could affect tourism demand in the ASEAN-5 countries. This finding was in accordance with the economic theory that showed that the relationship between tourism price and tourist arrivals was significant and negatively related in ASEAN-5 countries. The findings further indicated that a $1 \%$ decrease in tourism price would 
increase tourism demand by $0.33 \%$ in the long run. In this regard, the findings were further confirmed by a previous study, where a negative relationship between tourism price and tourist arrivals was established, (Norlida Hanim Mohd Salleh, 2011). The increase in tourism price can be the impact of certain factors, which can indirectly reduce tourist arrivals in each country. Among the factors that could affect tourism price are the changes in exchange rate, changes in technology, and seasonal variations. These results were in accord with the expectation that tourism price will increase with the increase in the exchange rate. Nonetheless, the negative correlation had not significantly affect tourism demands from the Middle East to Malaysia, (Norlida Hanim Mohd Salleh, 2011).

Income per capita was also reported as a significant variable in this paper. The result showed that income has a positive effect on tourism demands in ASEAN-5 countries. The results also showed that the $1 \%$ increase in income per capita would increase tourist arrival by $0.59 \%$ in the long run. These results were in accord with the expectation that the demand for goods and services will increase with increasing income per capita. In addition, to maintain income priority, the exchange rate must maintain at the competitive price. The high level of income and a strong propensity to travel among residents might contribute to the prosperity of certain tourism sectors, (Yang \& Wong, 2013). In other words, higher income per capita can cause different effects on the increased tourist arrivals. The long run elasticity of the degree of trade was 1.09 , which indicated that when the level of trade was increased by $1 \%$, it would increase tourist arrivals by $1.09 \%$. The relationship with the trade was positive. This was because when trade demand from outsiders was increased, tourist arrivals would increase at the same time. The positive relationship between trade and tourism demand in this study was consistent with the findings of (Shan \& Wilson, 2001). They found a strong relationship between international trade and international travel in Australia and China.

The results have shown that carbon dioxide emission has a negative effect on tourism demand in ASEAN-5 countries. The results showed that $1 \%$ increase of carbon dioxide emission would lead to a decrease of $-1.17 \%$ tourist arrivals in the long run. This significant effect of carbon dioxide emission on tourism demand in ASEAN-5 countries was consistent with the findings of (Bode et al., 2003). The implications of environmental issues, such as its contribution to greenhouse gases and global warming could also affect tourist activities. The empirical evidence indicated that income and trade appeared to exert significant positive impacts on tourism demand, whereas tourism price and carbon dioxide emissions have negative impacts in the long run. The existence of a long run relationship (dynamic stability) and the coefficient on the error correction term should be negative. As seen in Table 4, the error correction coefficient estimates were negative with the dynamically stable ranges for PMG, MG, and DFE estimators. This coefficient was significantly negative for the PMG, MG and DFE estimators, which supported the dynamic stability of the model. The results from this study showed that the pooling led to a much smaller speed of adjustment and its corresponding standard error. The estimate of the speed of adjustment was approximately $9 \%$ for the PMG, $22 \%$ for the MG, and 5\% for the DFE, depending on the factors of tourism demand. This study has concluded that the PMG estimate was closer to the DFE estimate but different from the MG estimate for the long run coefficients. In addition, this study has also found that pooling had sharpened estimates considerably; the PMG and DFE estimates were more significant compared with the MG estimate, while the standard error of the PMG and DFE were much smaller than of the MG estimate. Therefore, in the long run, homogeneity restriction cannot be rejected at the conventional level by the Hausman test statistic. This result indicated that the PMG estimates preferable than the MG estimates. The results for PMG estimates in the long run coefficients were $-0.3268,0.5909,1.0939$, and -1.1688 , with the standard errors of $0.1467,0.2782,0.2908$, and 0.4961 for tourism price, income per capita, trade, and carbon dioxide emission, respectively. These values implied that higher international tourism demand could indirectly improve tourist arrivals in the long run. The MG estimates were consistent in either case. The Hausman test rejected the null hypothesis that the PMG estimator was efficient, at a significance level of $10 \%$, but not at $1 \%$. Hence, the argument for MG estimator was weak. 


\subsubsection{Results for Short run Estimates}

Meanwhile, the short run estimates had revealed a different concept. This was because the short run were not restricted to be the same across countries. The short run estimates can be analysed by considering the mean of the responding coefficient in the short run effect. Based on Table 4, the long run homogeneity restriction had also reduced the standard error in the tourism demand coefficient. This was because the PMG approach had allowed the short-term dynamic specification to be different for each country. The PMG estimates of the short run effect were negative and significant, ranging from 0.024 to 0.23 . The higher tourism price can hinder the increase of tourist arrivals in ASEAN-5 countries when the short run average estimates were negative. Technological changes and the change in the price factor could have negative effects on tourism demand in ASEAN-5 countries, which is one of the possible negative effects in the short run. This observation suggested that the short-term tourism demand could be significantly influenced by tourism price, income per capita, trade, and carbon dioxide emission $\left(\mathrm{CO}_{2}\right)$. When comparing between the long run and short run estimates, it was found that the number of tourist arrivals depended on whether their movements were temporary or permanent. Moreover, the coexistence of positive long run effects and negative short run effects implied that although tourist arrivals could impede tourism demand in the short-term, indirectly, the tourism demand in the long run would be higher.

\section{Conclusion}

This study aimed to analyze and determine the main factors that could affect tourism demand in ASEAN-5 countries, namely Malaysia, Indonesia, Singapore, Thailand and the Philippines. Panel Data analysis, with Pooled Mean Group (PMG), Mean Group (MG) and Dynamic Fixed Effect (DFE) were applied. This paper had also analyzed the long run and short run relationship between tourist arrivals and tourism price, income per capita, trade and carbon dioxide emission. The result showed that the PMG had performed better than the MG estimators. Income and trade appeared to exert significant positive relationship on tourism demand, whereas tourism price and carbon dioxide emissions have negative relationships with tourism demand in ASEAN-5 countries. These results were consistent with the theory of demand and were statistically significant. In this paper, almost all variables had fulfilled their expectations, with satisfactory levels of significant. These results of this study were also quite similar to the findings of previous literature.

Based on these results, the elasticity of variables, which could influence tourism demand, had not varied compared to the previous study by (Norlida Hanim Mohd Salleh, 2011). Relatively, tourism price was found to be elastic, but this study found that the tourism price in Asean-5 countries was elastic. In other words, the increase in tourism price would not have a positive effect on tourist arrivals. This hypothesis was supported by (Norlida Hanim Mohd Salleh, 2011) whose study showed that the negative relationship between tourism price was insignificant and elastic, which did not affect tourism demand from the Middle East to Malaysia. The results also showed that tourism demand was very sensitive to changes in the tourism price. In other words, the increase of tourism price would cause tourism demand to fall drastically. Therefore, to ensure that tourism price can attract tourist arrivals, the policymakers and stakeholders must closely monitor all tourism service providers, such as hospitality facilities, to ensure that they do not charge unreasonable prices for their services. Furthermore, the income from tourism demand in ASEAN-5 countries was elastic. In other words, the decrease in income would lead to an increase in tourist arrivals. For instance, (Norlida Hanim Mohd Salleh, 2011) income has positive and significantly relationship with tourism demand, from the Middle East to Malaysia. The economic theory suggests that the demand for goods and survives will increase with increasing income. The increase in income will simultaneously lead to an increase in tourist arrivals. However, this case would depend on the current situations. The stakeholders need to improve the quality of products and services to upgrade to luxury items with higher income elasticity. Meanwhile, the results showed that the carbon dioxide emission was inelastic. Tourism demand showed less sensitivity to the level of rising carbon 
dioxide emission. These results showed that all determinant factors that were affecting tourism demand in ASEAN-5 countries were significant. In addition, income per capita and trade showed a positive relationship, while tourism price and carbon dioxide showed a negative relationship. These findings were consistent with previous studies by (Norlida Hanim Mohd Salleh, 2011; TOH, 2006). Therefore, to increase the rate of tourist arrivals, he responsible parties should be alert to the levels of carbon dioxide emission periodically. As for the implications of government policies, the ASEAN -5 governments should co-operate to improve their services and quality of standards. Policymakers must also closely monitor all tourism services. Other than that, policymakers should develop more policies on tourism safety and security to cope with the increasing demands.

\section{References}

Aktürk, T., \& Kucukozmen, C. C. (2006). Tourism Demand for Turkey: Models, Analysis and Results. Middle East Technical University, Institute of Applied Mathematics: Ankara.

Andriotis*, K. (2004). The perceived impact of tourism development by Cretan residents. Tourism and Hospitality Planning \& Development, 1(2), 123-144.

Antonakakis, N., Dragouni, M., \& Filis, G. (2015). How strong is the linkage between tourism and economic growth in Europe? Economic Modelling, 44, 142-155.

Association, P. A. T. (2015).

Authority, S. T. (2017). Tourism Development.

Baltagi, B. H., \& Giles, M. D. (1998). Panel data methods. Statistics Textbooks and Monographs, 155, 291-324.

Bank, W. D. (2016). World Data Bank. Retrieved 10 May 2017

Bestard, A. B., \& Nadal, J. R. (2007). Modelling environmental attitudes toward tourism. Tourism Management, 28(3), 688-695.

Bode, S., Hapke, J., \& Zisler, S. (2003). Need and options for a regenerative energy supply in holiday facilities. Tourism Management, 24(3), 257-266.

Chaitip, P., Chaiboonsri, C., \& Rangaswamy, N. (2008). A Panel Unit Root and Panel Cointegration Test of the Modeling International Tourism Demand in India. VOL. VIII PART I, 95.

Council, T. W. T. a. T. (2016).

Crouch, G. I. (1994). The study of international tourism demand: a review of findings. Journal of Travel Research, 33(1), 12-23.

Dollar, D., \& Kraay, A. (2003). Institutions, trade, and growth. Journal of Monetary Economics, 50(1), 133-162.

Dritsakis, N. (2005). Tourism as a long-run economic growth factor: an empirical investigation for Greece using causality analysis. Tourism Economics, 10(3), 305-316.

Engle, R. F., \& Granger, C. W. (1987). Co-integration and error correction: representation, estimation, and testing. Econometrica: Journal of the Econometric Society, 251-276.

Garcia, R. C., Contreras, J., Van Akkeren, M., \& Garcia, J. B. C. (2005). A GARCH forecasting model to predict day-ahead electricity prices. IEEE transactions on power systems, 20(2), 867-874.

Garin-Munoz, T., \& Amaral, T. P. (2000). An econometric model for international tourism flows to Spain. Applied Economics Letters, 7(8), 525-529.

Gu, H., \& Ryan, C. (2008). Place attachment, identity and community impacts of tourism-the case of a Beijing hutong. Tourism Management, 29(4), 637-647.

Johansen, S., \& Juselius, K. (1990). Maximum likelihood estimation and inference on cointegration - with applications to the demand for money. Oxford Bulletin of Economics and statistics, 52(2), 169-210.

Kim, D.-H., Lin, S.-C., \& Suen, Y.-B. (2010). Dynamic effects of trade openness on financial development. Economic Modelling, 27(1), 254-261.

Kosnan, S. S. A., Ismail, N. W., \& Kaliappan, S. R. (2013). Determinants of International Tourism in Malaysia: Evidence from Gravity Model. Jurnal Ekonomi Malaysia, 47(1), 131-138.

Kusni, A., Kadir, N., \& Nayan, S. (2013). International tourism demand in Malaysia by tourists from OECD countries: A panel data econometric analysis. Procedia Economics and Finance, 7, $28-34$.

Lee, J. W., \& Brahmasrene, T. (2013). Investigating the influence of tourism on economic growth and carbon emissions: Evidence from panel analysis of the European Union. Tourism Management, 38, 69-76.

Li, G. (2004). Tourism forecasting-an almost ideal demand system approach. Unpublished Ph. D. thesis, University of Surrey.

Li, G., Song, H., \& Witt, S. F. (2005). Recent developments in econometric modeling and forecasting. Journal of Travel Research, 44(1), 82-99. 
Lim, C. (1997). Review of international tourism demand models. Annals of Tourism Research, 24(4), 835-849.

López Bonilla, J. M. (2005). Efecto desestacionalizador del turismo rural en las regiones españolas. Boletín ICE económico(2860), 17-30.

McDowall, S., \& Choi, Y. (2010). A comparative analysis of Thailand residents' perception of tourism's impacts. Journal of Quality Assurance in Hospitality \& Tourism, 11(1), 36-55.

Mervar, A., \& Payne, J. E. (2007). An analysis of foreign tourism demand for Croatian destinations: long-run elasticity estimates. Radni materijali Ekonomskog instituta, Zagreb(1), 5-21.

Narayan, P. K. (2004). Fiji's tourism demand: the ARDL approach to cointegration. Tourism Economics, 10(2), 193-206.

Nation, S. A. (2016). Tourism Development.

Nation, U. (2013). Tourism Development.

Neal, T. (2015). The unbiased estimation of heterogeneous coefficients in panel data models with common factors and feedback effects. Retrieved from

Norlida Hanim Mohd Salleh, R. O. (2011). Penentu Faktor Ekonomi dan Bukan Ekonomi Terhadap Permintaan Pelancongan ke Malaysia. Prosiding PERKEM 4(2), 444-458.

Pesaran, M. H., Shin, Y., \& Smith, R. P. (1999). Pooled mean group estimation of dynamic heterogeneous panels. Journal of the American Statistical Association, 94(446), 621-634.

Pesaran, M. H., \& Smith, R. (1995). Estimating long-run relationships from dynamic heterogeneous panels. Journal of Econometrics, 68(1), 79-113.

Qureshi, M. I., Hassan, M. A., Hishan, S. S., Rasli, A. M., \& Zaman, K. (2017). Dynamic linkages between sustainable tourism, energy, health and wealth: Evidence from top 80 international tourist destination cities in 37 countries. Journal of Cleaner Production, 158, 143-155.

Research, A. T. (2011). Economics and The Tourism Industry.

Research, A. T. (2016). Economics and The Tourism Industry.

Ridderstaat, J., Oduber, M., Croes, R., Nijkamp, P., \& Martens, P. (2014). Impacts of seasonal patterns of climate on recurrent fluctuations in tourism demand: Evidence from Aruba. Tourism Management, 41, 245-256.

Schubert, S. F., Brida, J. G., \& Risso, W. A. (2011). The impacts of international tourism demand on economic growth of small economies dependent on tourism. Tourism Management, 32(2), 377-385.

Seddighi, H. R., \& Shearing, D. (1997). The demand for tourism in North East England with special reference to Northumbria: an empirical analysis. Tourism Management, 18(8), 499-511.

Shan, J., \& Wilson, K. (2001). Causality between trade and tourism: empirical evidence from China. Applied Economics Letters, 8(4), 279-283.

Sisay, D. (2015). Alternative Estimations of Manufactured Exports : mean-group , pooled mean-group and GMM estimators. Denmarks Statistic, Modelgruppen, 15(1), 1-11.

Tang, C. F., \& Tan, E. C. (2015). Does tourism effectively stimulate Malaysia's economic growth? Tourism Management, 46, 158-163.

TOH, R. S. K., Habibullah Goh, Lynette. (2006). Japanese demand for tourism in Singapore: A cointegration approach. Tourism Analysis, 10(4), 369-375.

Trebicky, V., \& Cihar, M. (2006). Analysis of Nature-Based Tourism in the Sumava National Park, Czech Republic: 1997-2004. Exploring the Nature of Management, 233.

Witt, S. F., \& Witt, C. A. (1995). Forecasting tourism demand: A review of empirical research. International Journal of Forecasting, 11(3), 447-475.

Wu, S.-T., \& Chen, Y.-S. (2015). The social, economic, and environmental impacts of casino gambling on the residents of Macau and Singapore. Tourism Management, 48, 285-298.

Yang, Y., \& Wong, K. K. (2013). Spatial distribution of tourist flows to China's cities. Tourism Geographies, $15(2), 338-363$.

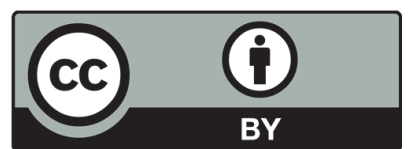

(C) 2018 by the authors; licensee Growing Science, Canada. This is an open access article distributed under the terms and conditions of the Creative Commons Attribution (CC-BY) license (http://creativecommons.org/licenses/by/4.0/). 